\title{
THE HABSBURG AND TRANSYLVANIAN AIMS RELATED TO THE CAMPAIGN OF THE OTTOMANS AGAINST THE POLISH-LITHUANIAN COMMONWEALTH (1634) ${ }^{1}$
}

\author{
János Szabados \\ http://orcid.org/0000-0001-5288-0386 \\ University of Szeged (Hungary) \\ MTA-SZTE Research Group of the Ottoman Age (ELKH), Szeged (Hungary)
}

\begin{abstract}
In 1634 the Ottoman Emperor, Murad IV (r. 1623-1640), decided to lead a campaign against the Polish-Lithuanian Commonwealth. He wanted to request military support from the Prince of Transylvania, György Rákóczi I (r. 1630-1648), but the prince tried to avoid it, because at that time he had been struggling with his political enemies, who endangered his rule in Transylvania. In the same year, the Habsburgs sent an ambassador (Johann Rudolf von Puchheim) to Constantinople, who tried to dissuade the Sublime Porte from leading a military campaign against the Polish-Lithuanian Commonwealth. The idea of that mediation came from the former Vizier of Buda and at that time, the commander of the Ottoman army, Pasha Murteza, because he did not want this war either. Prince Rákóczi, Puchheim, Trzebiński (Aleksander, the Polish envoy) and Murteza all wanted to stall for time in relation to that campaign. In this article, the author investigates the aims and the problem-solving strategies of the Habsburg, the Transylvanian, the Polish and also the Ottoman elite in that situation. The war against the Polish-Lithuanian Commonwealth did not take place in the end, because Murad IV began a campaign against the Safavid Empire.
\end{abstract}

Keywords: Polish-Ottoman conflicts, Principality of Transylvania, Habsburg diplomacy, diplomatic mediation.

1 The research related to this paper was supported by the Ministry of Human Capacities (Emberi Erőforrások Minisztériuma) through the grant (code no. 20391-3/2018/FEKUSTRAT). The research was supported by the Tempus Public Foundation through the Collegium Hungaricum Scholarship (COHU2018-2019-282313). This paper is written as a contribution of the Interdisciplinary Centre of Excellence, the Department of Medieval and Early Modern Hungarian History (Faculty of Humanities and Social Sciences) (University of Szeged), and the MTA-SZTE Research Group of the Ottoman Age. 


\section{INTRODUCTION}

In this paper I investigate the East European political events of the year 1634. These events seemed to be important not only for the two great empires of the early modern age, the Habsburg Monarchy ${ }^{2}$ and the Ottoman Empire, ${ }^{3}$ but also for the Polish-Lithuanian Commonwealth ${ }^{4}$ and the Ottoman vassal state, Transylvania. ${ }^{5}$ Firstly, I present the European political situation of that period with regard to both empires, and also the local political context in Poland and Transylvania. Secondly, I examine the reasons of the decision of Sultan Murad IV ${ }^{6}$ about launching a campaign against the Polish-Lithuanian Commonwealth in 1634, and the reasons and aims of the Habsburg grand embassy led by Count Johann Rudolf von Puchheim (1600-1651). ${ }^{7}$ Additionally, I look at the strategies employed by the Polish, Transylvanian and Habsburg diplomacy at Constantinople and Adrianople to hinder the looming Ottoman campaign. Although the campaign against Poland did not take place eventually, it is worth investigating as the event has not been scrutinised from the Habsburg and Transylvanian perspectives so far.

In the following I present the concrete aims and activity of the Habsburg, Transylvanian and Polish diplomats. I outline their cooperation and strategies to persuade the Ottoman government to avoid a war with the Polish-Lithuanian Commonwealth. It

2 For the Habsburg Monarchy in that period, see: G. Pálffy, The Kingdom of Hungary and the Habsburg Monarchy in the Sixteenth Century, New York 2009, pp. 53-208; M. Hochedlinger, P. Mat' a, T. Winkelbauer (eds.), Verwaltungsgeschichte der Habsburgermonarchie in der Frühen Neuzeit. Bd. 1/1. Hof und Dynastie, Kaiser und Reich, Zentralverwaltungen, Kriegswesen und landesfürstliches Finanzwesen, Wien 2019.

3 For the Ottoman Empire in that period, see: S. Show, History of the Ottoman Empire and Modern Turkey, vol. 1: Empire of the Gazis: The Rise and Decline of the Ottoman Empire, 1280-1808. Cambridge 1976, pp. 169-213; G. Ágoston, B. Masters (eds.), Encyclopedia of the Ottoman Empire, New York 2009, passim. For the relation of the two empires, see: M. Kurz, M. Scheutz, K. Vocelka, T. Wink elbau er (eds.), Das Osmanische Reich und die Habsburgermonarchie. Akten des internationalen Kongresses zum 150-jährigen Bestehen des Instituts für Österreichische Geschichtsforschung, Wien, 2225. September 2004, Wien-München 2005.

4 For Poland in that period see the studies of the following volume: R. Butterwick (ed.), The Polish-Lithuanian Monarchy in European Context, c. 1500-1795, Belfast 2001.

5 For the Transylvanian foreign policy during the rule of György Rákóczi I, see: I. Lukinich, “Bethlen István támadása 1636-ban, I-V,” Századok 1910, pp. 24-40, 98-112, 212-227, 299-314, 477-494; G. Kármán, "The Polish-Ottoman-Transylvanian Triangle: A Complex Relationship in the Sixteenth and Seventeenth Centuries" [in:] Türkiye-Polonya Illişkilerinde „Temas Alanları” 14142014 Uluslararası Konferansı Bildiriler Kitabi, eds. H. Topaktaş, N. Królikowska, Ankara 2017, pp. 305-316; G. Kármán, “II. Gusztáv Adolf és Erdély fejedelmei,” Századok 2018, no. 4, pp. 739765; J.B. Szabó, "Két díván Budán. I. Rákóczi György erdélyi fejedelem és a magyarországi oszmán hódoltság elitje (1630-1636)," Történelmi Szemle 2019, no. 2, pp. 247-265.

6 For Murad IV's short biography, see: G. Börekçi, "Murad IV" [in:] Encyclopedia of the Ottoman Empire, pp. 403-404.

7 H.F. Schwarz, The Imperial Privy Council in the Seventeenth Century, Cambridge 1943, pp. 326-327. 
was possible to achieve their common aim, because the Viziers of the Porte also held different views about the necessity of that campaign.

\section{THE SOURCES AND LITERATURE USED}

In my research I used some archival sources retrieved from the Austrian State Archives (Österreichisches Staatsarchiv = ÖStA), namely from the Haus- Hofund Staatsarchiv (HHStA) Türkei I. Kt. (box) 113, which contains the correspondence of the year 1634, in connection to the Habsburg grand embassy to Constantinople, the reports of the resident ambassador (1629-1643) at the Ottoman capital, Johann Rudolf Schmid (1590-1667), ${ }^{8}$ and also the final report of the grand ambassador, Count Johann Rudolf von Puchheim. ${ }^{9}$ In addition to this, I perused the Transylvanian sources published mostly in the $19^{\text {th }}$ century. ${ }^{10}$ These contain numerous pieces of information with regard to this Ottoman campaign, because György Rákóczi ${ }^{11}$ was also concerned about these events due to the domestic affairs of Transylvania. Furthermore, I used the work of Franz Christoph von Khevenhüller (which is most probably based on the final report of Puchheim), ${ }^{12}$

8 For Schmid's activity, see: P. Meienberger, Johann Rudolf Schmid zum Schwarzenhorn als kaiserlicher Resident in Konstantinopel in den Jahren 1629-1643. Ein Beitrag zur Geschichte der diplomatischen Beziehungen zwischen Österreich und der Türkei in der ersten Hälfte des 17. Jahrhunderts, Bern-Frankfurt am Main 1973, pp. 59-142.; ÖStA HHStA, Türkei I, Kt. 113, Konv. 1 and Bd. 2, Schmid's reports to Ferdinand II and Johann Rudolf Puchheim, passim.

9 Puchheim's final report and his correspondence during his mission, see: ÖStA HHStA, Türkei I, Kt. 113, Bd. 1, Bd. 2, Johann Rudolf Puchheim to Ferdinand II, Vienna, September 10, 1634, passim.

10 Á. Szilády, S. Szilágyi (eds.), Török-magyarkori Államokmánytár, II. kötet, Pest 1869, pp. 197-225; A. Beke (ed.), Pázmány, Lippay és Eszterházy levelezése I. Rákóczy Györggyel, Budapest 1882, pp. 13-25; S. Szilágyi (ed.), Levelek és okiratok I. Rákóczy György Keleti összeköttetései történetéhez, Budapest 1883, pp. 172-209, 232-242; A. Beke, S. Barabá s (eds.), I. Rákóczi György és a Porta: Levelek és okiratok, Budapest 1888, pp. 98-132.

11 For György Rákóczi I, see: S. Szilágyi, I. Rákóczy György 1593-1648, Budapest 1893.

12 „.. . zu dem Ende sie [Ihre Kayserliche Majestät] dann Herrn Hannß Rudolph Grafen von Pucham nach Constantinoplel zu Ende des vergangenen Jahrs abgefertigt, der von seiner gantzen Reise und Verrichtung eine ansehnliche weitläufige Relation gethan, aus der die Substanz dem Leser zur Nachrichtung hieher gesetzt worden.” F.Ch. Khevenhüller, der Erste zu Aichelberg, Annales Ferdinandei Oder Wahrhaffte Beschreibung Kaysers Ferdinandi des Andern, mildesten Gedächtniß, Geburth, Aufferziehung und bißhero in Krieg und Friedens-Zeiten vollbrachten Thaten, geführten Kriegen, und vollzogenen hochwichtigen Geschäfften. 12., darinnen Kaeysers und Koenigs Ferdinand Handlungen wegen Kriege in Deutschland, wie auch alle denckwuerdige Geschichte vom Anfange des 1632 biß zu Anfang des 1637 Jahrs beschrieben werden samt kurzer Erzehlung deren in der gantzen Welt von höchstgedachter kaeyserl. Majestät Geburthen biß auf derselben seeligsten Hintritt, das ist von Anfang des 1578 biß auf das 1637 Jahr vorgelauffenen Handlungen und denckwürdigen Geschichten; in zwölf Theilen mit vielen Kupffern, Leipzig 1726, p. 1391. For the whole document, see: pp. 1391-1445, http://digital.bib-bvb.de/view/bvbmets/viewer.0.6.4.jsp?folder_id=0\&dvs=1564309389207 573\&pid=3 $68608 \&$ locale=hu\&usePid1 =true\&usePid2=true [accessed: July 28, 2019]. 
Sándor Szilágyi, ${ }^{13}$ Joseph Hammer-Purgstall ${ }^{14}$ and Johann Wilhelm Zinkeisen, ${ }^{15}$ as well as the recent literature on this topic. ${ }^{16}$

\section{THE GLOBAL AND LOCAL POLITICAL CONTEXTS IN 1634}

The determining event of the European politics in the examined period was definitely the Thirty Years War (1618-1648), ${ }^{17}$ because most of the European states were more or less involved in this war. Therefore, one of the most concerned states, the Habsburg Monarchy, was highly interested in keeping peace with the Ottoman Empire. ${ }^{18}$ At the end of February 1634, the Habsburg "Generalissimus" Albrecht Wallenstein was murdered by an assassin in order to hinder his conspiration, because he tried to turn against his Emperor. ${ }^{19}$ After that, on August 27, 1634, the new commander, Archduke Ferdinand (later also Emperor Ferdinand III, r. 1637-1657), led the imperial troops at Nördlingen to victory against the protestant alliance..$^{20}$ At that time the Ottoman Empire also intended to maintain peace with the Habsburg Monarchy, because they were at war in the East with the Safavid Empire between 1623 and 1639 , and also several rebellions took place during that time in the whole empire. ${ }^{21}$

13 S. Szilágyi, I. Rákóczy György, pp. 248-255.

14 J. von Hammer-Purgsta11, Geschichte des Osmanischen Reiches. Großentheils von bisher unbenützten Handschriften und Archiven. Bd. 5. Vom Regierungsantritte Murad des Vierten bis zur Ernennung Mohammed Köprili's zum Grosswesir. 1623-1656, Pest 1829, pp. 177-183.

15 J.W. Zinkeisen, Geschichte des Osmanischen Reiches in Europa. Vierter Theil. Zunehmender Verfall und neuer Aufschwung des Reiches bis zu dem Frieden zu Vasvar und dem Falle von Candia in den Jahren 1664 und 1669, Gotha 1856, pp. 473-477, 504-512.

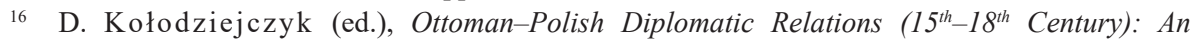
Annotated Edition of 'Ahdmanes and Other Documents, Leiden 2000, pp. 137-139; J.B. Szabó, "Két díván Budán," pp. 258-261.

17 For the Thirty Years War in general, see: J.Ph. Cooper (ed.), The Decline of Spain and the Thirty Years War. (1609-1648/59) The New Cambridge Modern History, Cambridge 1971, pp. 306-358; G. Parker, The Thirty Years' War, London-New York 1997, pp. 33-163.

18 For the situation, see: I. Hiller, Palatin Nikolaus Esterházy: Die ungarische Rolle in der Habsburgerdiplomatie 1625-1645, Esterházy-Studien, Wien-Köln-Weimar 1992, pp. 22-32; M. Köhbach, "Warum beteiligte sich das Osmanische Reich nicht am Dreißigjährigen Krieg?" [in:] Polen und Österreich im 17. Jahrhundert, eds. W. Leitsch, S. Trawkowski, Wien-Köln-Weimar 1999, pp. 277-294.

19 L. Höbelt, Ferdinand III (1608-1657) Friedenskaiser wider Willen, Graz 2008, pp. 63-68; G. Mortimer, Wallenstein: The Enigma of the Thirty Years War, Basingstoke 2010, pp. 221-239; M. Hengerer, Kaiser Ferdinand III (1608-1657). Eine Biographie, Wien-Köln-Weimar 2012, pp. 94 101.

${ }^{20}$ For Ferdinand III's activity in that period, see: L. Höbelt, Ferdinand III, pp. 63-76; M. Hengerer, Kaiser Ferdinand III, pp. 101-111.

21 J. von Hammer-Purgstall, Geschichte, pp. 4-22, 26-35, 46-66, 72-87, 101-126, 129-160, 164-173, 193-211, 216-271; J.W. Zinkeisen, Geschichte, pp. 53-177. For more information about (Great) Shah Abbas and his campaign, see: G. Brandl, Cs. Göncöl, K. Juhász, G.E. Marton, 
In April 1634, Murad IV left Constantinople and moved to Adrianople due to the military preparations against Poland. ${ }^{22}$

Besides the global political context, manifold local political environments existed which influenced the aims of the Eastern European states. A campaign of the Ottomans in 1621 ended in an Ottoman failure and a peace treaty had to be signed between Sultan Osman II (r. 1618-1622) and King Sigismund III (r. 1587-1632)23 and later another agreement had to be signed in $1630 .{ }^{24} \mathrm{In} 1633$, due to the plundering of the Cossacks, Pasha Abaza Mehmed tried to attack the Commonwealth while the Polish were fighting against the Russians. ${ }^{25}$

As for Transylvania, Prince György Rákóczi I managed to establish his rule in Transylvania only in 1633 , because in that year he signed a treaty with the Hungarian King, Ferdinand II (r. 1619-1637). ${ }^{26}$ However, the pretender to his throne, Mózes Székely Jr. (1603-1652), ${ }^{27}$ was able to flee to Constantinople and he was supported by the adversary of the Prince and that is why Rákóczi had to make efforts to get rid of him. He wanted Mózes Székely to be either imprisoned or sent into exile by the Ottoman government. ${ }^{28}$ During these attempts Rákóczi received the mandate of the Ottoman Emperor in the spring of 1634, according to which, he also had to move with the Transylvanian troops against Poland. ${ }^{29}$

\section{COMMON INTERESTS}

These pieces of information also show that three of the four above-mentioned states were not interested in a war on the Polish-Ottoman border due to their numerous domestic or diplomatic problems. 1) The Habsburg Monarchy intended to

J. Szaba dos, "Kommunikáció és híráramlás. A Habsburg-oldal tárgyalási stratégiája az 1627. évi szőnyi békekötés során," Aetas 2018, no. 4, pp. 110-111.

22 J. von Hammer-Purgstall, Geschichte, p. 178; J.W. Zinkeisen, Geschichte, p. 509.

23 D. Kołodziejczyk (ed.), Ottoman-Polish, pp. 130-135.

24 Ibidem, pp. 135-136.

${ }_{25}$ J.von Hammer-Purgstall, Geschichte, pp. 175-178; J.W. Zin ke is e n, Geschichte, pp. 505507; D. Kołodziejczyk (ed.), Ottoman-Polish, p. 137.

26 S. Szilágyi, I. Rákóczy György, pp. 232-248.

27 For the biography of Mózes Székely Jr., see: S. Papp, "II. Rákóczi György és a Porta” [in:] Szerencsének elegyes forgása. II. Rákóczi György és kora, eds. A.P. Szabó, G. Kármán, Budapest 2009, pp. 106-107, 119, 130-131, 138, 143-144; G. Kármán, Erdélyi külpolitika a vesztfáliai béke után, Budapest 2011, pp. 50, 142-144, 207, 231, 234; S. Papp, Török szövetség - Habsburg kiegyezés. A Bocskai-felkelés történetéhez, Budapest 2014, pp. 56-57, footnote 183.

28 For the activity of Mózes Székely Jr. in that time, see: I. Lukinich, "Bethlen István támadása," pp. 34-35, 100-103, 214, 220, 224-225, 298-300, 311, 487, 489.

29 J.B. S z a b ó, “'Splendid Isolation'? The Military Cooperation of the Principality of Transylvania with the Ottoman Empire (1571-1688) in the Mirror of Hungarian Historiography's Dilemmas" [in:] The European Tributary States of the Ottoman Empire in the Sixteenth and Seventeenth Centuries, eds. G. Kármán, L. Kunčević, Leiden-Boston 2013, p. 323. 
maintain the peace with the Ottomans by all means. Thus, it was the most important reason why Puchheim was sent to the Sublime Porte. ${ }^{30}$ As the ambassador left Vienna, the Ottoman-Polish conflict had not yet been known at the Habsburg Court, but the Aulic War Council did not want to intervene directly in that confrontation. ${ }^{31}$ 2) The Polish King, Władysław IV (r. 1632-1648) ${ }^{32}$ wanted to let the Sublime Porte know about his succession to the throne and to avoid the Ottoman attack. That is why he sent his ambassador, Aleksander Trzebiński, to Constantinople. ${ }^{33}$ Later, in August 1634, Władysław sent another envoy (Jakub Zieliński) to the Ottoman capital again in order to renew the peace. ${ }^{34}$ 3) György Rákóczi I did not endeavour to take part in that campaign either, and he sent his envoy, István Szalánczy, to Adrianople ${ }^{35}$ and later in the summer another envoy, Ferenc Mikó ${ }^{36}$ to Pasha Murteza (1581?-1636). ${ }^{37}$ Rákóczi also maintained an intensive contact with his agent (István Réthi) ${ }^{38}$ in Constantinople.

\section{THE DIPLOMATIC MISSION OF ALEKSANDER TRZEBIŃSKI AND JOHANN RUDOLF VON PUCHHEIM}

According to the reports of István Réthi, Pasha Abaza Mehmed did not intend to allow Trzebiński to travel to Constantinople, but despite Abaza's design, the ambassador finally arrived in the Ottoman capital on March $1,1634 .{ }^{39}$ On the evidence of the reports of Habsburg diplomats, Trzebiński was permitted to have an audience with the Sultan on March 15. Murad seemed to be quite unfriendly during the audi-

30 ÖStA HHStA, Türkei I, Kt. 113, Bd. 2, Ferdinand II to Johann Rudolf Puchheim, Vienna, December 22, 1633, fol. $143 \mathrm{v}-148 \mathrm{v}$.

31 The first instructions related to the Polish affair were sent to Puchheim on June 8 and 9, 1634. ÖStA HHStA, Türkei I, Kt. 113, Bd. 2, Ferdinand II to Johann Rudolf Puchheim, Vienna, June 8 and 9 , 1634, fol. 289-290, 328.

32 S. Gebei, II. Rákóczi György külpolitikája 1648-1657, Budapest 2004, p. 13.

33 D. Kołodziejczyk (ed.), Ottoman-Polish, pp. 137-138.

34 Ibidem, pp. 138-139.

35 The instruction of Rákóczi to István Szalánczi, see: György Rákóczi I to István Szalánczi, Gyulafehérvár [Alba Iulia], June 14, 1634, Á. Szilá dy, S. Szilágyi, Török-magyarkori Államokmánytár, pp. 199-205. The report of Szalánczi to Rákóczi, see: István Szalánczi to György Rákóczi I, Constantinople, January 24, 1634. A. Beke, S. B arabás, I. Rákóczy György és a Porta, pp. 95-97.

36 The instructions of Rákóczi to Ferenc Mikó, see: György Rákóczi I to Ferenc Mikó, Szászsebes, August 21, 23, 26, 28 and September 4, 1634. Á. Szilády, S. Szilágyi, Török-magyarkori Allamokmánytár, pp. 205-225.

37 For the career of Pasha Murteza, see: A. Gévay, A budai pasák, Bécs 1841, p. 29.

38 The instructions of Rákóczi to István Réthi, see: György Rákóczi I to István Réthi, Gyulafehérvár [Alba Iulia], May 14, June 1, 28, 1634. Szászsebes [Sebeş], August 25, October 21, 1634. S. Szilágyi, Levelek és okiratok, pp. 195-199, 209-211; A. Beke, S. Barabás, I. Rákóczy György és a Porta, pp. 100-101, 106-108, 111-113, 119-121.

39 István Réthi to Ferenc Mikó, Constantinople, March 5, 1634. S. S zilá g y i, Levelek és okiratok, p. 183. 
ence and he demanded not only a yearly tribute from Poland, but the demolishing of several fortresses and the more effective bridling of the Cossacks as well. The ambassador was not commissioned to negotiate in the first two topics, so the Sultan threatened him that he would make peace with the Safavids and move with his whole army against Poland. ${ }^{40}$ Finally, Trzebiński was allowed to leave Constantinople in the company of an Ottoman diplomat, Agha Şahin, who was commissioned to negotiate with Władysław IV about the above-mentioned debated questions. ${ }^{41}$

Ferdinand II sent Johann Rudolf von Puchheim to the Sublime Porte in order to negotiate about the future commission in connection with the debated villages in Ottoman Hungary, about the duration of the last peace treaty in 1627, and he also brought some complaints about the Ottoman plundering in Hungary. ${ }^{42}$ As for Transylvania he had to cultivate good relations with the diplomats of Rákóczi, because the emperor supported Rákóczi as the Prince of Transylvania (Rákóczi was regarded as a Hungarian aristocrat and thus a subject of the Hungarian Kingdom) ${ }^{43}$ As for Poland, Puchheim did not have any instruction, indeed, because he was first informed about the military preparations of the Ottomans by the resident ambassador, Schmid, during his journey to Constantinople. ${ }^{44}$ The first time Puchheim has received an instruction from Vienna was on June 9, 1634, just on his return journey, that he should not directly mediate in connection with that conflict. ${ }^{45}$ Although he was not instructed with regard to the Polish affairs and the Turks, yet, first of all, the agent of the Vizier of Buda, then the Kaymakam and Pasha Murteza, tried to persuade him to mediate between them and the Polish. ${ }^{46}$ According to his report, Puchheim suggested that Trzebiński play for a time through the diplomatic mission of Agha Şahin and that suggestion seemed to be effective. ${ }^{47}$

40 For Trzebiński’s audience, see: ÖStA HHStA, Türkei I, Kt. 113, Konv. 1, Johann Rudolf Schmid to Ferdinand II, Constantinople, March 15, 1634, fol. 21-22.

${ }^{41}$ For the mission of Agha Şahin, see: D. Kołodziejczyk (ed.), Ottoman-Polish, pp. 138-139.

42 ÖStA HHStA Türkei I. Kt. 113. Bd. 2, Ferdinand II to Johann Rudolf Puchheim, Vienna, December 22, 1633, fol. 143v-148v.

43 ÖStA HHStA, Türkei I, Kt. 113, Bd. 2, Ferdinand II to Johann Rudolf Puchheim, Vienna, December 22, 1633, fol. 131. For the debate about the political relations of the Kingdom of Hungary and the Princes of Transylvania, see: S. Gebei, "Az erdélyi fejedelmek legitimációjának kérdéséhez" [in:] Tanulmányok Erdély fejedelemség-kori történetéböl, eds. D. Ballabás, Z. Borbély, Eger 2012, pp. 37-52; G. Kármán, "Pax és pacificatio. Kísérlet egy fogalmi tisztázásra a Magyar Királyság és az Erdélyi Fejedelemség viszonyának megértése érdekében,” Történelmi Szemle 2016, no. 2, pp. 341-353; for György Rákóczi I as a subject of the Hungarian King, see: G. Kármán, Erdélyi külpolitika, p. 51.

44 ÖStA HHStA, Türkei I, Kt. 113, Bd. 2, Johann Rudolf Schmid to Johann Rudolf Puchheim, Constantinople, February 10, 1634, fol. 208; ÖStA HHStA, Türkei I, Kt. 113, Bd. 1, Final report of Johann Rudolf Puchheim, Vienna, September 10, 1634, fol. 77.

45 ÖStA HHStA, Türkei I, Kt. 113, Bd. 2, Ferdinand II to Johann Rudolf Puchheim, Vienna, June 9, 1634, fol. 290 .

46 ÖStA HHStA, Türkei I, Kt. 113, Bd. 1, Final report of Johann Rudolf Puchheim, Vienna, September 10, 1634, fol. 85-86., 88-90.

47 ÖStA HHStA, Türkei I, Kt. 113, Bd. 1, Final report of Johann Rudolf Puchheim, Vienna, September 10, 1634, fol. 90 . 


\section{THE DIPLOMATIC AIMS OF GYÖRGY RÁKÓCZI I}

At the beginning of the year 1634, the most important political aim of Rákóczi was that Mózes Székely should be sent in exile from Constantinople as soon as possible. According to recent research, Rákóczi was abandoned by his former supporters in the Ottoman Empire (by the group known as his "political family") at that time, and that is why it seemed to be not too easy for him to carry out his intention at the Sublime Porte. ${ }^{48}$ The Prince also followed the events in Poland with attention, because he informed his envoy (Ferenc Mikó) sent to Constantinople at the beginning of 1634 about the news of the Polish-Russian war. ${ }^{49}$ On the evidence of his instructions, Rákóczi came to know the intention of the Ottomans against the Polish-Lithuanian Commonwealth as early as December 30,1633, and he also knew that they wanted him to participate in that campaign. ${ }^{50}$

In the spring, parallel to the diplomatic mission of the Habsburg ambassador and the military preparations of the Ottomans, Rákóczi kept asking his agent via his letters whether the Sultan in person or someone else as a serdar (commander) would lead the troops and what the general intent of the government was at the Sublime Porte: war or peace with Poland; and in case of peace, what their other intentions were (e.g. with Mózes Székely). ${ }^{51}$ Later, he sent his envoy, István Szalánczi, to Adrianople in order to inquire whether the Sultan really wanted him to join the campaign with his troops and whether the Viziers were on the same opinion as the Sultan and Pasha Abaza or not. ${ }^{52}$ Rákóczi was also interested in the delay of that campaign, so he supported the journey of Agha Şahin, because the Hungarian Archbishop (1616-1637) and Cardinal (1629-1637), Péter Pázmány (1570-1637), also suggested him the temporization..$^{53}$ The Prince informed the Sultan about the mobilization of his troops, but he was only waiting and did nothing against Poland. He tried to win the influential personages around the Sultan for his aim (e.g. some Viziers, the Seyhulislam and, of course, Pasha Murteza) with gifts so that they would not support that Rákóczi go

48 For these "political families," see: J.B. Szabó, B. Sudár, "Independens fejedelem az Portán kívül” II. Rákóczi György oszmán kapcsolatai. Esettanulmány az Erdélyi fejedelemség és az Oszmán Birodalom viszonyának történetéhez (1. rész)," Századok 2012, no. 5, pp. 1027-1035. For the political families in that time period, see: J.B. Szabó, "Két díván Budán,” pp. 249-250, 254-258.

49 György Rákóczi I to Ferenc Mikó. Gyulafehérvár [Alba Iulia], December 14, 1633, A. Beke, S. Barabás, I. Rákóczi György és a Porta, p. 92.

50 György Rákóczi I to Ferenc Mikó. Fiátfalva [Filiaş], December 30, 1633, S. Szilágyi, Levelek és okiratok, pp. 178-179.

51 György Rákóczi I to István Réthi, Gyulafehérvár [Alba Iulia], place unknown, May 14, June 28, date unknown, 1634, A. Beke, S. Barabás, I. Rákóczi György és a Porta, pp. 98-100, 100-101, 106-108; György Rákóczi I to István Réthi, Gyulafehérvár [Alba Iulia], June 20, 1634. S. Szilágyi, Levelek és okiratok, pp. 195-198.

52 György Rákóczi I to István Szalánczi, Gyulafehérvár [Alba Iulia], June 14, 1634, Á. Szilády, S. Szilágyi, Török-magyarkori Államokmánytár, pp. 199-203.

53 Péter Pázmány to György Rákóczi I, Pozsony [Bratislava], March 22, 1634, F. Hanuy (ed.), Pázmány Péter bíbornok, esztergomi érsek, Magyarország herczegprimása összegyüjtött levelei. II. Kötet. (1629-1637), Budapest 1911, pp. 474-475. 
against Poland. ${ }^{54}$ Despite his efforts, it seems that it was not because of Rákóczi that the Sultan finally changed his mind and did not move against Poland.

\section{THE KEY PERSON: PASHA MURTEZA}

The key person in connection with the Ottoman campaign against Poland was Pasha Murteza, because the representatives of all the involved states tried to contact him. At that time, he considered one of the most influential Viziers, because he had been a friend of the former Sultan, Ahmed I (r. 1603-1617), the father of Murad IV. Also, he had been the Vizier of Buda between 1626 and 1630, and in 1627 he had negotiated as plenipotentiary with the Habsburgs about the prolongation of the peace between the two empires. ${ }^{55}$

According to the sources, all the afore-mentioned diplomats had access to Pasha Murteza in order to win him for their (mostly common) purposes. It must have been a rumour in Constantinople that Murteza did not support the impending campaign and that is why all interested parties tried to contact him. Puchheim visited the Pasha on April 4, because he was invited by him to an audience directly after his audience with the Sultan. ${ }^{56}$ Murteza seemed to be the person who suggested Trzebiński visit Puchheim. ${ }^{57}$ Therefore, he should be called the real mediator, because after the meeting of the two ambassadors (the Polish was allowed to meet only the Habsburg ambassador and no other Christian representatives), ${ }^{58}$ the Pasha invited Puchheim one more time to negotiate about the Polish affairs. ${ }^{59}$ On April 9, the Habsburg ambassador could reassure Trzebiński about the mission of Agha Şahin. ${ }^{60}$

54 György Rákóczi to István Szalánczi, Gyulafehérvár [Alba Iulia], June 14, 1634, Á. Szilády, S. Szilágyi, Török-magyarkori Államokmánytár, pp. 201-203.

55 For the career and correspondence of Pasha Murteza, see: A. Gévay, A budai pasák, 29; F. Salamon, Két magyar diplomata a tizenhetedik századból, Pest 1867, passim; G. Brandl, Cs. Göncöl, K. Juhász, G.E. Marton, J. Szabados, "Válogatott források az 1627. évi szőnyi békekötés történetéhez," Lymbus 2017, pp. 155-158, 168-173; G. Brand1, Cs. Göncö1, K. Juhász, G.E. Marton, J. Szabados, "Kommunikáció és híráramlás," pp. 122-124. Gábor Kármán and his fellow researchers are presently working on the publishing of the Hungarian letters of Pasha Murteza in the framework of the OTKA project Diplomáciai források a Magyar Királyság oszmán kapcsolatainak történetéhez (16-17. század) (no. 124178 OTKA-project).

56 ÖStA HHStA, Türkei I, Kt. 113, Bd. 1, Puchheim's Final Relation, Vienna, September 1, 1634, fol. $87-88$.

57 Trzebiński visited Puchheim on April 6, 1634. cf. ÖStA HHStA, Türkei I, Kt. 113, Bd. 1, Puchheim's Final Relation, Vienna, September 10, 1634, fol. 89.

58 This piece of information originated from Schmid. Cf. ÖStA HHStA, Türkei I, Kt. 113, Konv. 1, Johann Rudolf Schmid to Ferdinand II. Constantinople, March 15, 1634, fol. 23.

59 ÖStA HHStA, Türkei I, Kt. 113, Bd. 1, Puchheim's Final Relation, Vienna, September 10, 1634, fol. 89-90.

60 ÖStA HHStA, Türkei I, Kt. 113, Bd. 1, Puchheim's Final Relation, Vienna, September 10, 1634, fol. 92. 
Later, when Murteza was assigned as the commander of the troops against the Polish-Lithuanian Commonwealth, Rákóczi, of course, tried to persuade him about the unnecessity of that campaign. The envoy of the Pasha (Dervish Agha) told the Prince that the Porte wanted Rákóczi to assist as Gábor Bethlen (r. 1613-1629) had done before, which means that Rákóczi could have been elected as King of Poland just as it had been the plan of his predecessor. ${ }^{61}$ But Rákóczi was afraid and he let Cardinal Pázmány know that during his absence, Mózes Székely could be put by the Ottomans in his position, and in case he did not move with the Ottoman troops, the whole Ottoman army could move against Transylvania, because at that time the army was garrisoned in Gyurgyevó (present day Giurgiu in Romania). ${ }^{62}$

After the Polish victory against the Russians, Władysław IV sent an envoy to Murteza and to Constantinople which also underlined the key position of the Pasha. The content of the letter addressed to Murteza is known, because a Hungarian translation of it survived. Władysław IV wrote to Murteza that he would have liked to keep peace and hoped that Murteza did also the same and he had sent his envoy in order to negotiate about the new peace. ${ }^{63}$ Rákóczi was aware of the content of that letter and suggested that Murteza do not forward it to Constantinople, because he should make peace on his own responsibility and then he should inform the Sublime Porte about the peace as before in the case of the Habsburg-Ottoman peace treaty in 1627. The reason for that suggestion was Rákóczi's anxiety about Transylvania, as the Polish wanted to include Transylvania in the peace treaty, too, but Rákóczi did not know anything about these conditions. ${ }^{64}$

\section{CONCLUSIONS}

The Ottomans finally did not move on with their attack, Pasha Abaza Mehmed was executed, the Empire entered into peace with Poland and the next year Murad IV led the Ottoman troops against the Safavids. As for the aims of the three abovementioned states, the following can be established. 1) According to the peace treaty,

${ }^{61}$ György Rákóczi I to Ferenc Mikó, Szászsebes [Sebeş], August 23, 1634. Á. Szilády, S. Szilágyi, Török-magyarkori Államokmánytár, p. 208. For the plans of Gábor Bethlen about the throne of Poland, see: Cs. Németh, "Melyik út vezet Magyarország trónjához? (Bethlen Gábor 1628-1629-es keleti terve, és annak diplomáciai háttere)," Aetas 1987, no. 3, pp. 9-19; G. Kármán, The Polish-OttomanTransylvanian Triangle, pp. 301-302; G. Kármán, “II. Gusztáv Adolf,” pp. 733-739.

${ }^{62}$ György Rákóczi I to Péter Pázmány, place unknown, August 24, 1634, A. Beke, Pázmány, Lippay és Eszterházy, pp. 19-21.

${ }_{63}$ Władysław IV to Pasha Murteza, Warsaw, July 5, 1634, S. Szilágyi (ed.), Rozsnyai Dávid történeti maradványai, Budapest 1877, pp. 200-204. This copy must have been made by the Hungarian renegade, Zülfikár Aga. Cf. G. Kármán, “Zülfikár aga portai fötolmács,” Aetas 2016, no. 3, p. 58, footnote 17 .

${ }^{64}$ György Rákóczi I to Ferenc Mikó, Szászsebes [Sebeş], August 8, 1634, Á. Szilády, S. Szilágyi, Török-magyarkori Államokmánytár, pp. 214-215. 
the Polish-Lithuanian Commonwealth did not have to pay tax to the Ottoman Empire hereafter, as has been the case earlier, but they were obliged to keep the Cossacks in check ${ }^{65}$ so in the case of the Polish-Ottoman relations this treaty can be called a no-win situation. 2) The Habsburg diplomacy could reach its goal, because they did not have to choose between the two states in the case of war and they could maintain peace with the Ottomans, but the planned commission on the border about the debated villages did not take place hereafter. 3) Rákóczi could be relieved, on the one hand, because he did not have to provide support the Ottomans against his also Christian neighbour, but his efforts remained fruitless with regard to Mózes Székely ${ }^{66}$ Although Rákóczi was able to keep his throne, Mózes Székely could be used in the future as a hostage with whom Rákóczi could be blackmailed by the Ottomans.

It was only the common interest of the three states that was realized, but the peace with Poland depended only partly on their efforts, because they needed the mediation of Pasha Murteza. The peace between the Ottoman Empire and the Polish-Lithuanian Commonwealth was influenced also by the international political situation (the threat of the Safavid Empire) and the final decision was eventually made by the Ottoman Emperor.

\section{BIBLIOGRAPHY}

\section{Archival Materials}

Österreichisches Staatsarchiv (Vienna), Haus-, Hof- und Staatsarchiv, Türkei I.

Kt. 113.

Konv. 1.

Bd. 2, 3.

\section{Primary Sources Published}

Beke A. (ed.), Pázmány, Lippay és Eszterházy levelezése I. Rákóczy Györggyel, Budapest 1882.

Beke A., Barabás S. (eds.), I. Rákóczi György és a Porta: Levelek és okiratok, Budapest 1888.

Brandl G., Göncöl Cs., Juhász K., Marton G.E., Szabados J., "Válogatott források az 1627. évi szőnyi békeszerződés történetéhez”, Lymbus 2017, pp. 151-203.

Hanuy F. (ed.), Pázmány Péter bíbornok, esztergomi érsek, Magyarország herczegprímása összegyüjtött levelei, II. Kötet (1629-1637), Budapest 1911.

65 D. Kołodziejczyk (ed.), Ottoman-Polish, pp. 439-440.

${ }_{66}$ Mózes Székely remained in Constantinople and was used by the Ottomans hereafter as a hostage until his death in 1652. Cf. S. Papp, II. Rákóczi György és a Porta, pp. 106-107, 119, 130-131, 138, 143; G. Kármán, Erdélyi külpolitika, pp. 142, 144, 207, 230-231, 234-235. 
Khevenhüller der Erste zu Aichelberg F.Ch., Annales Ferdinandei Oder Wahrhaffte Beschreibung Kaysers Ferdinandi des Andern, mildesten Gedächtniß, Geburth, Aufferziehung und bißhero in Krieg und Friedens-Zeiten vollbrachten Thaten, geführten Kriegen, und vollzogenen hochwichtigen Geschäfften. 12., darinnen Kaeysers und Koenigs Ferdinand Handlungen wegen Kriege in Deutschland, wie auch alle denckwuerdige Geschichte vom Anfange des 1632 biß zu Anfang des 1637 Jahrs beschrieben werden samt kurzer Erzehlung deren in der gantzen Welt von höchstgedachter kaeyserl. Majestät Geburthen biß auf derselben seeligsten Hintritt, das ist von Anfang des 1578 biß auf das 1637 Jahr vorgelauffenen Handlungen und denckwürdigen Geschichten; in zwölf Theilen mit vielen Kupffern, Leipzig 1726, pp. 1391-1445, http://digital.bib-bvb.de/view/bvbmets/viewer.0.6.4.jsp?folder_id $=0 \& d v s=1564309389207 \sim 573 \&$ pid $=368608 \&$ locale $=$ hu \&usePid1=true\&usePid2=true [accessed: July 28, 2019].

Salamon F. (ed.), Két magyar diplomata a tizenhetedik századból, Pest 1867.

Szilády Á., Szilágyi S. (eds.), Török-magyarkori Államokmánytár, vol. II, Pest 1869.

Szilágyi S. (ed.), Levelek és okiratok I. Rákóczy György Keleti összeköttetései történetéhez, Budapest 1883.

Szilágyi S. (ed.), Rozsnyai Dávid történeti maradványai, Budapest 1877.

\section{Literature}

Ágoston G., Masters B. (eds.), Encyclopedia of the Ottoman Empire, New York 2009.

Brandl G., Göncöl Cs., Juhász K., Marton G.E., Szabados J., "Kommunikáció és híráramlás. A Habsburg-oldal tárgyalási stratégiája az 1627. évi szőnyi békekötés során”, Aetas 2018, no. 4, pp. 108-124.

Butterwick R. (ed.), The Polish-Lithuanian Monarchy in European Context, c. 1500-1795, Belfast 2001.

B. Szabó J., Sudár B., “'Independens fejedelem az Portán kívül:’ II. Rákóczi György oszmán kapcsolatai. Esettanulmány az Erdélyi fejedelemség és az Oszmán Birodalom viszonyának történetéhez (1. rész)”, Századok 2012, no. 5, pp. 1017-1048.

B. Szabó J., “'Splendid Isolation'? The Military Cooperation of the Principality of Transylvania with the Ottoman Empire (1571-1688) in the Mirror of Hungarian Historiography's Dilemmas" [in:] The European Tributary States of the Ottoman Empire in the Sixteenth and Seventeenth Centuries, eds. G. Kármán, L. Kunčević, Leiden-Boston 2013, pp. 301-339.

B. Szabó J., "Két díván Budán. I. Rákóczi György erdélyi fejedelem és a magyarországi oszmán hódoltság elitje (1630-1636)", Történelmi Szemle Budapest (2019), no. 2, pp. 247-265.

Cooper J. Ph. ed., The Decline of Spain and the Thirty Years War (1609-1648/59), The New Cambidge Modern History, Cambridge 1971.

Gebei S., II. Rákóczi György külpolitikája 1648-1657, Budapest 2004.

Gebei S., "Az erdélyi fejedelmek legitimációjának kérdéséhez" [in:] Tanulmányok Erdély fejedelemség-kori történetéböl, eds. D. Ballabás, Z. Borbély, Eger 2012, pp. 37-52.

Gévay A., A'budai pasák, Vienna 1841.

Hammer-Purgstall J. von, Geschichte des Osmanischen Reiches. Großentheils von bisher unbenützten Handschriften und Archiven. Bd. 5. Vom Regierungsantritte Murad des Vierten bis zur Ernennung Mohammed Köprili's zum Grosswesir. 1623-1656, Pest 1829.

Hengerer M., Kaiser Ferdinand III (1608-1657). Eine Biographie, Wien-Köln-Weimar 2012. 
Hiller I., Palatin Nikolaus Esterházy: Die ungarische Rolle in der Habsburgerdiplomatie 1625-1645, Esterházy-Studien, Wien-Köln-Weimar 1992.

Hochedlinger M., Mat'a P., Winkelbauer T. (eds.), Verwaltungsgeschichte der Habsburgermonarchie in der Frühen Neuzeit. Bd. 1/1. Hof und Dynastie, Kaiser und Reich, Zentralverwaltungen, Kriegswesen und landesfürstliches Finanzwesen, Wien 2019.

Höbelt L., Ferdinand III (1608-1657) Friedenskaiser wider Willen, Graz 2008.

Kármán G., Erdélyi külpolitika a vesztfáliai béke után, Budapest 2011.

Kármán G., "Pax és pacificatio. Kísérlet egy fogalmi tisztázásra a Magyar Királyság és az Erdélyi Fejedelemség viszonyának megértése érdekében”, Történelmi Szemle 2016, no. 2, pp. 341-353.

Kármán G., "The Polish-Ottoman-Transylvanian Triangle: A Complex Relationship in the Sixteenth and Seventeenth Centuries” [in:] Türkiye-Polonya İlişkilerinde ,,Temas Alanları” 1414-2014 Uluslararası Konferansı Bildiriler Kitabi, eds. H. Topaktaş, N. Królikowska, Ankara 2017, pp. 305-316.

Kármán G., “II. Gusztáv Adolf és Erdély fejedelmei”, Századok 2018, no. 4, pp. 739-765.

Kármán G., "Zülfikár aga portai fötolmács”, Aetas 2016, no. 3, pp. 54-76.

Kołodziejczyk D. (ed.), Ottoman-Polish Diplomatic Relations (15 th $-18^{\text {th }}$ Century): An Annotated Edition of 'Ahdmanes and Other Documents, Leiden 2000.

Köhbach M., "Warum beteiligte sich das Osmanische Reich nicht am Dreißigjährigen Krieg?" [in:] Polen und Österreich im 17. Jahrhundert, eds. W. Leitsch, S. Trawkowski, Wien-Köln-Weimar 1999, pp. 277-294.

Kurz M., Scheutz M., Vocelka K., Winkelbauer T. (eds.), Das Osmanische Reich und die Habsburgermonarchie. Akten des internationalen Kongresses zum 150-jährigen Bestehen des Instituts für Österreichische Geschichtsforschung. Wien, 22-25. September 2004, Wien-München 2005.

Lukinich I., "Bethlen István támadása 1636-ban, I-V”, Századok 1910, Pp. 24-40, 98-112, 212-227, 299-314, 477-494.

Pálffy G., The Kingdom of Hungary and the Habsburg Monarchy in the Sixteenth Century, New York 2009.

Meienberger P., Johann Rudolf Schmid zum Schwarzenhorn als kaiserlicher Resident in Konstantinopel in den Jahren 1629-1643. Ein Beitrag zur Geschichte der diplomatischen Beziehungen zwischen Österreich und der Türkei in der ersten Hälfte des 17. Jahrhunderts, Bern-Frankfurt am Main 1973.

Mortimer G., Wallenstein: The Enigma of the Thirty Years War, Basingstoke 2010.

Németh Cs., "Melyik út vezet Magyarország trónjához? (Bethlen Gábor 1628-1629-es keleti terve, és annak diplomáciai háttere)", Aetas 1987, no. 3, pp. 5-22.

Papp S., "II. Rákóczi György és a Porta” [in:] Szerencsének elegyes forgása. II. Rákóczi György és kora, eds. A.P. Szabó, G. Kármán, Budapest 2009, pp. 99-170.

Papp S., Török szövetség - Habsburg kiegyezés. A Bocskai-felkelés történetéhez, Budapest 2014.

Parker G., The Thirty Years' War, London-New York 1997.

Schwarz H.F., The Imperial Privy Council in the Seventeenth Century, Cambridge 1943.

Show S., History of the Ottoman Empire and Modern Turkey, vol. 1: Empire of the Gazis: The Rise and Decline of the Ottoman Empire, 1280-1808, Cambridge 1976.

Szilágyi S., I. Rákóczy György 1593-1648, Budapest 1893.

Zinkeisen J.W., Geschichte des Osmanischen Reiches in Europa. Vierter Theil. Zunehmender Verfall und neuer Aufschwung des Reiches bis zu dem Frieden zu Vasvar und dem Falle von Candia in den Jahren 1664 und 1669, Gotha 1856. 